\title{
MAREK KLUZ \\ Współczesny kontekst refleksji nad chrześcijańską etyką małżeńską i rodziną
}

Współczesna cywilizacja staje się często przyczyną głębokich schorzeń człowieka i prowadzi do zagubienia wartości małżeństwa i rodziny. Małżeństwo i rodzina staje przed różnego rodzaju pokusami zagubienia swej istoty i zafałszowania swoich fundamentalnych celów i zadań. Nasilają się też ataki na tradycyjne małżeństwo i rodzinę. Dokument Rady ds. Rodziny Konferencji Episkopatu Polski pt. Stużyć prawdzie o matżeństwie i rodzinie stwierdza wyraźnie: W ostatnich latach obserwujemy z bólem mnożące się naciski zarówno na płaszczyźnie ideologicznej, jak $i$ w sferze prawodawstwa, których celem jest zniszczyć tradycyjne matzeństwo i rodzinę, na których opiera się nasza cywilizacja, oraz promować rozwiazłość. Ubolewamy, że wiele z tych dziatań znajduje swa inspiracje badź oparcie $w$ niektórych organizacjach społecznych naszego Kraju, w polskim Parlamencie, w instytucjach ONZ oraz w Parlamencie Europejskim. Niektóre działania sa tak trywialne, że wprost nieprawdopodobne, ale przecież niosa przerażające w skutkach spustoszenie ${ }^{1}$.

Współczesne zjawisko kontestacji nauczania moralnego Kościoła na temat małżeństwa i rodziny wskazuje więc na potrzebę nie tylko dobrego zrozumienia i przedstawiania zasad etycznych w tej jakże ważnej dziedzinie, ale także na konieczność dobrego odczytania określonych uwarunkowań współczesności: pew-

Marek K L U Z, ks. dr, adiunkt Katedry Teologii Moralnej i Duchowości Wydziału Teologicznego Sekcja w Tarnowie Uniwersytetu Papieskiego Jana Pawła II w Krakowie, sekretarz WTST. e-mail: mkluz@op.pl

\footnotetext{
${ }^{1}$ Rada ds. Rodziny Konferencji Episkopatu Polski: Stużý prawdzie o matżeństwie i rodzinie. Warszawa $2009 \mathrm{nr} 7$.
} 
nych tendencji i zjawisk, które przyczyniają się do takiego a nie innego podejścia do określonych problemów moralnych.

Szczególne niebezpieczeństwo dla małżeństwa i rodziny płynie z szerzącego się permisywizmu moralnego, który preferuje różne sposoby destrukcji życia małżeńskiego i rodzinnego. Dlatego słusznie jest wołanie papieża Jana Pawła II: Żadne społeczeństwo ludzkie nie może ryzykować permisywizmu w sprawach tak podstawowych jak istota matżeństwa i rodziny! Tego typu permisywizm moralny w swych konsekwencjach musi szkodzić samemu społeczeństwu, jego autentycznej spoistości spotecznej i humanistycznej².

$\mathrm{Z}$ tej papieskiej wypowiedzi jasno wynika, że odpowiedź chrześcijańska na permisywizm moralny jest tylko jedna: jest to ewangelizacja małżeństwa i rodziny. Adhortacja Jana Pawła II Familiaris consortio mówi tak: Kościót oświecony wiarą, która pozwala mu poznać cała prawdę o wielkiej wartości matżeństwa $i$ rodziny oraz o ich głębokim znaczeniu, czuje się przynaglony do głoszenia Ewangelii - »dobrej nowiny - wszystkim bez wyjatku, a zwłaszcza ludziom powołanym do matżenstwa i przygotowujacym się do niego, wszystkim matżonkom $i$ rodzicom całego świata. Jest on głęboko przekonany, że jedynie przyjęcie Ewangelii pozwala na spetnienie wszystkich nadziei, które człowiek stusznie pokłada $w$ matżeństwie i rodzinie ${ }^{3}$.

\section{Permisywne tendencje w dziedzinie życia małżeńskiego i rodzinnego}

Zanim zostaną omówione pewne zjawiska i postawy permisywne w dziedzinie moralności małżeńskiej i rodzinnej, należy najpierw wskazać na tendencje natury ogólniejszej, w których ujawnia się sytuacja moralna dzisiejszego świata. Można mówić zarówno o pozytywnych, jak i negatywnych znakach czasu. Jeśli w prezentacji niniejszej zostały wyakcentowane bardziej sprawy i problemy natury raczej negatywnej, to z tego względu, że to właśnie one wskazują na zasadnicze przyczyny niezrozumienia i odrzucenia zasad etycznych w dziedzinie małżeństwa i rodziny oraz stanowią ważny wyznacznik dla pastoralnego oddziaływania Kościoła, który powinien umieć przeciwstawić się negatywnym tendencjom współczesności.

Odnosząc się do ogólnej sytuacji moralnej dzisiejszego świata można w zasadzie jedynie wspomnieć o pewnych istotnych zjawiskach i tendencjach (w tym miejscu nie sposób omawiać je szczegółowo). Najszerszą perspektywę wyznacza

\footnotetext{
${ }^{2}$ J a n P a w e 1 I I: List do Rodzin. Rzym 1994 nr 7 (dalej: LdR).

${ }^{3}$ J a n P a we 1 I I: Adhortacja apostolska Familiaris consortio. Watykan $1981 \mathrm{nr} 3$ (dalej: FC).
} 
tu zapewne dość powszechne zjawisko zagubienia moralnego poszczególnych ludzi i całych społeczności. Cechą charakterystyczną tego zjawiska jest z jednej strony brak integralnej wizji życia ludzkiego, brak sensu i celu życia, a z drugiej - zachwiana lub nawet odrzucona obiektywna hierarchia wartości.

Z tym zagubieniem moralnym wiąże się także taka koncepcja życia ludzkiego, w której dobro zostało utożsamione z tym, co łatwe i przyjemne. Na pierwszym miejscu wielu ludzi stawia to, co przynosi egoistyczną przyjemność albo określoną korzyść, co prowadzi do postaw hedonistycznych i utylitarystycznych. Takie nastawienie życiowe prowadzi do społeczeństwa permisywnego, do zjawiska permisywizmu moralnego, czyli do postaw łatwego zwalniania się z obowiązków i odrzucanie zasad, które wymagają jakiegoś wysiłku i trudu. Można to nazwać „obniżaniem poprzeczki” wymagań moralnych w duchu rzekomego zagwarantowania ,praw" człowieka. Prowadzi to w sposób oczywisty do relatywizmu moralnego, a więc odrzucenia istnienia absolutnych norm moralnych. Wskazując na zmienność życia ludzkiego, chce się z tego wyprowadzić wniosek, że także wszelkie zasady moralne mają jedynie czasowy charakter ${ }^{4}$.

Najbardziej objawia się to w tzw. sytuacjonizmie etycznym (etyce sytuacyjnej). Jedyną normą i wyznacznikiem życia ludzkiego staje się wówczas sytuacja życiowa danego człowieka. Zwolennicy tej tendencji w etyce nie przyjmują istnienia powszechnie obowiązujących zasad moralnych, albo nie widzą potrzeby odwoływania się do nich, gdyż w samej sytuacji i we własnym rozeznaniu człowiek ma znaleźć wyznaczniki swego zachowania moralnego. W sposób oczywisty rodzi to skrajny subiektywizm moralny ${ }^{5}$.

Można też mówić o postawie przesadnego zaufania i zawierzenia temu, co niesie ze sobą postęp techniczny i naukowy. Taka postawa prowadzi do swoistej supremacji mentalności technicznej. Charakteryzuje się ona przekonaniem, że najważniejsza jest skuteczność, najważniejsze jest osiągnięcie określonych celów, bez oglądania się na to, jakimi środkami się to dokonuje. Ten mit skuteczności sprawia, że wielu ludzi nie zastanawia się nad godziwością użytych środków i sposobów, zakładając - nie zawsze do końca świadomie - że cel uświęca środki. Człowiek współczesny tak często dzisiaj gubi cel i sens życia. Bezradny w tej sytuacji tak łatwo chce zastąpić to, co istotne w życiu różnymi namiastkami. Stąd tendencja, by więcej „mieć”, aniżeli bardziej „,być”。.

Wszystkie te zjawiska i tendencje mają swoje odbicie we współczesnej sytuacji małżeństwa i rodziny. Encyklika Dives in misericordia w punkcie 12 mówi

\footnotetext{
${ }^{4}$ Por. A. D r o żd ż: Permisywizm moralny. Kielce 2005 s. 81-97.

${ }^{5}$ Por. tamże, s. $57-75$ i $135-151$.

${ }^{6}$ Por. Sobór Watykański II: Konstytucja duszpasterska o Kościele w świecie współczesnym Gaudium et spes. W: Sobór Watykański II. Konstytucje. Dekrety. Deklaracje. Poznań 1968 nr 35 (dalej: KDK).
} 
wprost o permisywizmie moralnym, który godzi w najczulsza tkankę życia, jaka jest rodzina ${ }^{7}$. Godzi - jeśli tak można powiedzieć - poprzez destrukcję struktury rodziny i jej funkcjonowania. Permisywizm preferuje różne sposoby dzisiejszej destrukcji życia rodzinnego poprzez rozwody, małżeństwa na próbę, antykoncepcję, aborcję, sterylizację, eutanazję, sztuczne zapłodnienie, zamęt w pojmowaniu autorytetu rodziców i dzieci itp. Należy dodać, że pewne szczególne trudności we współczesnej sytuacji małżeństwa i rodziny związane są nie tylko z określonymi okolicznościami zewnętrznymi, ale także wynikają z odrzucenia doktryny Kościoła.

U podstaw zagrożeń życia małżeńskiego i rodzinnego leży wypaczenie samego rozumienia tych wspólnot. Nauka chrześcijańska pojmuje małżeństwo i rodzinę jako ,instytucje” naturalne, od Boga pochodzące, cieszące się wielką godnością i rządzone Bożym prawem. Tymczasem myśl permisywna chce sprowadzić małżeństwo i rodzinę do ,instytucji” użycia, wyzwolonej od odpowiedzialności i od wszelkich norm moralnych. Jednym z elementów permisywnego myślenia jest wzrastająca liczba rozwodów. Rozwody niszczą rodzinę i są zagrożeniem dla młodego pokolenia. Wprowadzając destabilizację w życie małżeńskie i rodzinne, osłabiają same podstawy życia społecznego. Obok plagi rozwodów coraz częstszym zjawiskiem stają się nowe związki cywilne, także wśród wierzących. Niekiedy poprzestaje się na zawieraniu jedynie cywilnych kontraktów małżeńskich, wbrew powołaniu ochrzczonych do przyjmowania sakramentu małżeństwa ${ }^{8}$.

Niemal sztandarowym przejawem permisywizmu, bardzo często spektakularnym i głośnym medialnie jest dumne preferowanie antykoncepcji. Antykoncepcją nazywamy taką ingerencję w funkcjonowanie organizmu kobiety i mężczyzny, która zarówno w przewidywaniu zbliżenia płciowego, jak i podczas jego spełnienia czy w rozwoju jego naturalnych skutków miałaby za cel uniemożliwienie poczęcia lub stanowiła środek prowadzący do tego celu ${ }^{9}$. Permisywna mentalność preferująca antykoncepcję zaszczepiła w ludziach przekonanie, że można podejmować życie płciowe bez myśli o ewentualnym potomstwie. Ludzie zaczęli traktować seks w sposób utylitarny. Rozprzestrzenia się opinię uzasadniającą potrzebę antykoncepcji głosząc, że człowiek musi być zawsze seksualnie aktywny i że nie może się czuć bezradnym wobec swoich seksualnych potrzeb, których nie potrafi, czy nie chce połączyć $\mathrm{z}$ miłością i odpowiedzialnością ${ }^{10}$.

\footnotetext{
${ }^{7} \mathrm{~J}$ a n P a w e 1 I I: Encyklika Dives in misericordia. Watykan $1983 \mathrm{nr} 12$.

${ }^{8}$ Por. J. P a ł y g a: Duszpasterstwo rodzin żyjacych w nowych zwiazkach. Częstochowa 2003 s. 12-15. P. S a 1 u m: Żyjacy w separacji, rozwiedzeni. Odnaleźć nadzieję. Tłum. M. P l e c i ń s k a. Poznań 1997 s. 134-139.

${ }^{9}$ Por. P a w e $\nmid$ V I: Encyklika Humanae vitae. Watykan 1968 nr 14 (dalej: HV).

${ }^{10}$ Por. FC 32. Por. także: S. M o j e k: Antykoncepcja promocja czy degradacja matżeńskiej miłości. W: Problemy wspótczesnego Kościoła. Red. M. R u s e c k i. Lublin 1996 s. 465.
} 
Kościół uczy, że antykoncepcja jest złem, ponieważ jest naruszeniem samego celu i natury aktu seksualnego, a tym samym godności osoby ludzkiej. Bóg zlecił małżonkom misję przekazywania życia. Antykoncepcja oznacza odmowę pełnienia tej misji; kto stosuje antykoncepcję pragnie „ekscytującego” fizycznego przeżycia, ale nie chce pozwolić Bogu na dokonanie aktu stwórczego. W takim akcie seksualnym występuje nadużycie daru ciała, polegające na podporządkowaniu prawa Bożego ludzkiej manipulacji. Osobę i jej zdolność przekazywania życia traktuje się instrumentalnie i destrukcyjnie. Takie zbliżenie stoi w sprzeczności z naturą i jest przykładem dominacji techniki nad etyką. Wszystkie techniki antykoncepcyjne są nieetyczne, są działaniem contra naturam, naruszają porządek moralny, który jest dziełem Boga ${ }^{11}$.

$\mathrm{Z}$ tego samego powodu antykoncepcja prowadzi często do aborcji. Wśród wszystkich przestępstw skierowanych przeciw życiu, jakie człowiek może popełnić, na pierwszy plan wysuwa się w ostatnim czasie właśnie przerywanie ciąży. Aborcja jest nie tylko problemem medycznym, ale przede wszystkim moralnym, podnoszonym przez całe rzesze filozofów, teologów i lekarzy. Dyskusja o aborcji nie daje chwili wytchnienia opinii publicznej wewnątrz i poza Kościo$ł_{\mathrm{em}}{ }^{12}$. Encyklika Evangelium vitae mówi o niedopuszczalności aborcji w punktach 57-63. Świadoma i dobrowolna decyzja pozbawienia życia niewinnej istoty ludzkiej jest zawsze ztem z moralnego punktu widzenia i nigdy nie może być dozwolona ani jako cel, ani jako środek do dobrego celu (...). Nikt i nic nie może dać prawa do zabicia niewinnej istoty ludzkiej, czy to jest embrion czy płód, dziecko czy dorosty ${ }^{13}$.

Z powyższych słów jasno wynika, że niedopuszczalna jest także praktyka zapłodnienia in vitro. Dyskusja wokół sztucznego zapłodnienia, której również podobnie jak aborcja - jesteśmy świadkami obecnie w Polsce, ukazuje pewien sposób jej prowadzenia, który często ma niewiele wspólnego z rzeczową wymianą argumentów. Zwolennicy nie tylko dążą do przedstawienia sztucznego zapłodnienia $\mathrm{w}$ jak najlepszym świetle, ale jednocześnie dokonują licznych przekłamań, z których najbardziej specyficznym jest próba narzucenia nowego modelu etycznego, opierającego się na subiektywizmie, negującym istnienie obiektywnych i uniwersalnych norm moralnych ${ }^{14}$.

Zasadniczą perspektywę dla oceny tego typu działań wyznacza Jana Paweł II stwierdzając, że techniki sztucznej reprodukcji, które wydaja się stużyć życiu $i$ często sa stosowane $z$ ta intencja, w rzeczywistości stwarzają możliwość nowych

\footnotetext{
${ }^{11}$ Por. A. J. K a to lo: Bezdroża antykoncepcji. Lublin 2011 s. 29; K. K r a j w e s k i: Antykoncepcja-dlaczego nie?.W: Bezdroża antykoncepcji. Red. A. J. K a t o l o. Lublin 2001 s. 27.

${ }^{12}$ Por. szerzej - T. Ś 1 i p k o: Za czy przeciw życiu? Pokłosie dyskusji. Kraków 1992.

${ }^{13} \mathrm{~J}$ a n P a w e $\nmid$ I I: Encyklika Evangelium vitae. Watykan $1995 \mathrm{nr} 57$ (dalej: EV).

${ }^{14}$ Por. T. K r a j: Wokót dyskusji na temat zaptodnienia in vitro. „Teologia i Moralność”. T. 4: 2008 s. $116-117$.
} 
zamachów na życie. Sa one nie do przyjęcia z punktu widzenia moralnego, ponieważ oddzielaja prokreację od prawdziwie ludzkiego kontekstu aktu matżeńskiego, a ponadto stosujacy te techniki do dziś notuja wysoki procent niepowodzeń: dotyczy to nie tyle samego momentu zaptodnienia, ile następnej fazy rozwoju embrionu, wystawionego na ryzyko rychtej śmierci. Ponadto $w$ wielu przypadkach wytwarza się większa liczbę embrionów, niż to jest konieczne dla przeniesienia któregoś z nich do tona matki, a następnie te tak zwane »embriony nadliczbowe" sa zabijane lub wykorzystywane w badaniach naukowych, które rzekomo stużyć postępowi nauki i medycyny, a w rzeczywistości redukuja życie ludzkie jedynie do roli »materiatu biologicznego«, którym można swobodnie dysponowac ${ }^{15}$.

Permisywizm głosi także dopuszczalność eutanazji. Człowiek jest dzisiaj świadkiem prawdziwej wojny silnych przeciw słabym. Zmierza to do eliminacji osób stanowiących dla innych ciężar, albo po prostu ubogich i „,bezużytecznych" ${ }^{\text {. }}$. Dodatkowo działania podjęte przeciw życiu, które zbliża się ku końcowi, tracą charakter ,przestępstwa” i uzyskują status ,prawa”. I co najgorsze, żądają uznania ich pełnej legalności przez państwo. Według Katechizmu Kościoła katolickiego, eutanazja bezpośrednia, niezależnie od motywów $i$ środków, polegająca na położeniu kresu życiu osób upośledzonych, chorych lub umierajacych i jest moralnie niedopuszczalna ${ }^{17}$.

Narastająca praktyka legalizowania eutanazji jest niepokojącym i groźnym zjawiskiem. Nie tylko jest objawem degradacji moralnej współczesnych społeczeństw, ale również negatywnych skutków społecznych ${ }^{18}$. Jan Paweł II w jednym ze swoich przemówień stwierdził, że trzeba dzisiaj stawić czoła nowemu wyzwaniu, jakim jest legalizacja eutanazji. Nie wystarczy jednak przeciwstawić się tej śmiercionośnej tendencji na forum opinii publicznej. Konieczne jest jeszcze, aby spoteczeństwo i struktury samego Kościoła aktywnie staraty się zapewnić godziwa opieke człowiekowi umierajacemu. Bo żaden człowiek w chwili swojej śmierci nie powinien zostać opuszczony, osamotniony i pozbawiony opieki $1^{19}$.

${ }^{15}$ EV 14. Por. także: Kongregacja Nauki Wiary: Instrukcja Donum vitae. Rzym 1987 nr 4 (dalej: DV); Kongregacja Nauki Wiary: Instrukcja Dignitas personae. Rzym 2008 nr 12.

${ }^{16}$ Por. J. R a t z i n g e r: Problem zagrożeń życia ludzkiego. „L'Osservatore Romano”. Wydanie polskie. R. 12: $1991 \mathrm{nr} 7$ s. 5.

${ }^{17}$ KKK 2277. Por. EV 65; Kongregacja Doktryny Wiary: Deklaracja o eutanazji (26 czerwca 1980). W: Nauczanie Papieskie III, 1. Rok 1980. Poznań 1985 s. 822-823.

${ }^{18}$ Por. W. B o ł o z: Życie w ludzkich rękach. Podstawowe zagadnienia bioetyczne. Warszawa 1997 s. 156. Por. także - M. K l u z: Starość i jej problemy we wspótczesnej cywilizacji. W: Przestrzenie pracy socjalnej. Red. J. S t a 1 a. Tarnów 2010 s. 96-100.

${ }^{19} \mathrm{~J}$ a n $\mathrm{P}$ awe $\nmid$ I I: »Godność człowieka umierającego". Do uczestników zgromadzenia ogólnego Papieskiej Akademii „Pro Vita” (27 lutego 1999). W: Chrześcijanin wobec eutanazji. Red. K. G r y z, B. M i e 1 e c. Kraków 2001 s. 155. 
Oprócz omówionych powyżej sposobów destrukcji życia małżeńskiego i rodzinnego preferowanych przez permisywizm moralny warto jeszcze zwrócić uwagę na szkodliwość tego zjawiska w podejściu do wychowania. Permisywne podejście do wychowania upowszechniło się w drugiej połowie XX wieku. Tendencje permisywne $\mathrm{w}$ pedagogice i psychologii były bardzo popularne w USA (B. Spock, twórca pedagogiki antyautorytarnej). Permisywne wychowanie miało być - w zamierzeniu propagatorów - drogą do przezwyciężenia wcześniejszego rygoryzmu i autorytaryzmu, ale faktycznie doprowadziło do zlekceważenia wychowania, a w skrajnych przypadkach oznaczało kapitulację wobec wyzwań wychowawczych. Tak więc jedno skrajne podejście do wychowania, jakim był rygoryzm i autorytaryzm, zostało zastąpione drugą skrajnością, prowadzącą do zanegowania wychowania.

Wielu rodziców wierzy, że ich permisywna tolerancja wobec dzieci jest jedyną szansą dla zachowania dobrych relacji w rodzinie. Chęć uniknięcia wszelkich konfliktów rodzi pokusę przyzwalania dziecku na wszystko. Rezygnacja z wymagań wychowawczych prowadzi do tego, że dzieci są pozostawione same sobie, a tym samym pozbawione poczucia bezpieczeństwa. Szkodliwość permisywizmu wychowawczego trzeba oceniać po jego skutkach. Tego typu wychowanie jest głęboko indywidualistyczne i egoistyczne, rodzi postawy narcystyczne, nie uczy odpowiedzialności za siebie i innych. Rodzi przekonanie u młodych, że każde żądanie musi być zaspokojone i że nie ma żadnych ograniczeń w ich stawianiu $^{20}$.

W propagowaniu zachowań permisywnych mają swój udział też środki społecznego przekazu, w których „rozmywa się” i ośmiesza tradycyjne wartości i normy moralne, niszczy się prawdziwe autorytety propagując wzorce i postawy, które nie odpowiadają obiektywnej prawdzie o człowieku, usprawiedliwia się różne formy przemocy, a także hedonistyczne i utylitarne podejście do życia. Stąd rodzi się obowiązek przeciwdziałania permisywizmowi moralnemu i amoralnej kulturze nie tylko w sferze teorii czy formacji specjalistycznej grupy działaczy, ale powstaje obowiązek zbiorowego i solidarnego działania wszystkich rodzin w celu przywrócenia społeczeństwu ludzkiego i chrześcijańskiego charakteru $^{21}$.

Jan Paweł II w adhortacji apostolskiej Familiaris consortio zwrócił uwagę na to, co leży u podstaw tych wszystkich negatywnych zjawisk. Chodzi tutaj o skażone pojęcie i przeżywanie wolności, rozumianej nie jako zdolność do realizowania prawdziwego zamystu Bożego wobec matżeństwa $i$ rodziny, ale jako autonomiczna siła, utwierdzająca $w$ dążeniu do osiagnięcia własnego egoistycz-

\footnotetext{
${ }^{20}$ Por. M. K 1 u z: Ponowoczesność jako wyzwanie moralne dla chrześcijańskiego wychowania dzieci w rodzinie. „Studia Regionalne”. R. 1: 2007 s. 176-178.

${ }^{21}$ Por. A. D r o ż d ż, dz. cyt., s. 181-194.
} 
nego dobra, nierzadko przeciw innym ${ }^{22}$. Niezbędne staje się zatem - pisze dalej papież - odzyskanie powszechnej świadomości prymatu wartości moralnych, które sq wartościami osoby ludzkiej jako takiej. Uświadomienie sobie na nowo ostatecznego celu życia i jego podstawowych wartości jest wielkim zadaniem dnia dzisiejszego, majacym na celu odnowe społeczeństwa ${ }^{23}$.

Ważne zadanie ma tu do spełnienia Kościól, który powinien znać te ludzkie pytania i problemy, aby na nie pełniej odpowiedzieć i odpowiednio ukierunkować swoje przepowiadanie, tym bardziej, że wpływ pewnych tendencji i zjawisk, szczególnie poprzez środki społecznej komunikacji, utrudnia przyjęcie pełnego orędzia chrześcijańskiego na temat małżeństwa i rodziny. Nierzadko się zdarza, $\dot{z} e$ mężczyźnie $i$ kobiecie $w$ ich szczerym $i$ dogtębnym poszukiwaniu odpowiedzi na codzienne i trudne problemy życia matżeńskiego i rodzinnego przedkłada się wizje $i$ kuszace propozycje, które $w$ różny sposób zdradzaja prawde $i$ godność osoby ludzkiej ${ }^{24}$. W dzisiejszym świecie, tak często nieprzychylnym, czy wręcz wrogim religii i krytycznie nastawionym do zasad moralnych, należy więc dopomóc małżeństwu i rodzinie w odkrywaniu piękna i wielkości powołania do miłości i służby życiu.

\section{Ewangelizacja małżeństwa i rodziny fundamentalnym wyzwaniem moralnym dla Kościoła}

W dialogu z myślą permisywną trzeba odwołać się do potrzeby ewangelizacji rodziny. Jest to dla Kościoła jedno z najważniejszych celów nowej ewangelizacji. Podjęcie przez Kościół dzieła głoszenia „ewangelii rodziny” ma na celu pogłębienie lub odnowienie poczucia odpowiedzialności każdej rodziny za dzieło ewangelizacji. Dzieło to obejmuje cztery podstawowe zadania: tworzenie wspólnoty osób, służbę życiu i wychowanie, uczestnictwo w życiu i posłannictwie Kościoła oraz udział w rozwoju społeczeństwa.

Nie ulega wątpliwości, że podstawą misji ewangelizacyjnej małżeństwa i rodziny jest podejmowanie działań na rzecz rozwijania prawdziwej wspólnoty (communio) osób ${ }^{25}$. W adhortacji apostolskiej Familiaris consortio Jan Paweł II wśród zadań rodziny na pierwszym miejscu wymienia tworzenie komunii osób. Czynnikiem sprawiającym tę komunię jest miłość. Rodzina, założona i ożywiana przez mitość, jest wspólnota osób: mężczyzny i kobiety jako matżonków, rodzi-

${ }^{22}$ FC 6.

23 Tamże, nr 8.

24 Tamże, nr 4

${ }^{25} \mathrm{~J}$. N a g ó r n y: Małżeństwo i rodzina jako »communio personarum«. W: Człowiek. Miłość. Rodzina. »Humanae vitae« po 30 latach. Red. J. N a gó r n y, K. J e ż y n a. Lublin 1999 s. 109115 . 
ców, dzieci i krewnych. Pierwszym jej zadaniem jest wierne przeżywanie rzeczywistości komunii w ciagłym działaniu na rzecz rozwijania prawdziwej wspólnoty osób ${ }^{26}$. W numerze 19 powyższego dokumentu można przeczytać, że podłożem wspólnoty rodzinnej jest przymierze miłości mężczyzny i kobiety. To przymierze opiera się na bezinteresownym darze. Jako pierwsza powstaje i rozwija się komunia pomiędzy matżonkami; na mocy przymierza miłości matżeńskiej, mężczyzna $i$ kobieta »już nie sa dwoje, lecz jedno ciało $i$ powotani sa do ciagtego wzrostu tej komunii poprzez codzienna wierność matżeńskiej obietnicy obopólnego catkowitego daru ${ }^{27}$.

Adhortacja Familiaris consortio zwraca dalej uwagę na budowanie komunii małżeńskiej w oparciu o naturalne potrzeby osoby. Owa komunia małżeńska ma swoje korzenie w naturalnym uzupełnianiu się mężczyzny i kobiety i jest wzmacniana przez osobistą wolę małżonków dzielenia całego programu życia, tego co maja i tego czym są. Stad taka komunia jest owocem i znakiem potrzeby głęboko ludzkiej ${ }^{28}$. Miłość i tworzenie communio personarum zostały wpisane w głębię natury mężczyzny i kobiety. Chrystus tę naturalną potrzebę wzmocni swoją łaską sakramentalną i podniósł do godności sakramentalnej.

Fundamentalne posłannictwo ewangelizacyjne małżeństwa i rodziny wyraża się następnie $\mathrm{w}$ jej uczestnictwie $\mathrm{w}$ służbie poczętemu życiu ${ }^{29}$. Zadanie to związane jest $\mathrm{z}$ tworzeniem wspólnoty osób. Zjednoczenie sakramentalne małżonków nie ogranicza się więc tylko do nich samych, lecz obejmuje także ich dzieci ${ }^{30}$. Wbrew pesymizmowi i egoizmowi świata, Kościół wyraźnie opowiada się za życiem $^{31}$. Uznając potomstwo za dar Boży, Kościół zdecydowanie twierdzi, że każde dziecko jest własnością Boga, jest darem Boga ${ }^{32}$. Małżonkowie mają więc moralny obowiązek być otwartymi na każde potomstwo i przyjąć je z miłością. Zabijanie dzieci nienarodzonych jest niedopuszczalne ${ }^{33}$. Ochrona poczętego życia jest zatem wielkim zobowiązaniem powołania chrześcijańskiego małżonków. Wszelkie poczynania, które zmierzają do ograniczenia w jakikolwiek sposób

${ }^{26}$ FC 18 .

27 Tamże nr 19

${ }^{28}$ Por. tamże.

${ }^{29}$ Szeroko na temat służby poczętemu życiu - odwołując się do dokumentów Kościoła - pisze w swojej publikacji - P. M o r c i n i e c: Stużba poczętemu życiu służba człowieczeństwu. Opole 1993 s. 20-246 oraz W. Gu b ała: Rodzina $w$ stużbie życia i miłości. Od »Humanae vitae« do »Evangelium vitae«. W: Człowiek droga kościoła. Moralne aspekty nauczania Jana Pawła II. Red. K. G r y z. Kraków 2004 s. 149-176.

${ }^{30}$ Por. KDK 52.

${ }^{31}$ Por. DV 76-77. Por. także - EV 53; KKK 2258.

${ }^{32}$ Mówił o tym wyraźnie J a n P a w e $\nmid$ I I w adhortacji apostolskiej Familiaris consortio: Życie ludzkie, nawet wtedy gdy jest stabe i cierpiace, jest zawsze wspaniatym darem Bożej dobroci (nr 30).

${ }^{33}$ Por. HV 14; EV 42,43. Por szerzej - Kongregacja Nauki Wiary: Deklaracja o przerywaniu ciąży Quaestio de abortu. Rzym 1975 nr 5-23. 
wolności małżonków w podejmowaniu decyzji co do potomstwa stanowią ciężką obrazę godności człowieka. W związku z tym - jak już zostało wspomniane Kościół oprócz aborcji zdecydowanie odrzuca też wszelkie działania antykoncepcyjne. Antykoncepcja niesie ze sobą urzeczowienie ciała i osoby. Kościół sprzeciwia się również sterylizacji, sztucznemu zapłodnieniu oraz manipulacjom genetycznym, które stanowią interwencję w Boży plan życia ${ }^{34}$.

Małżonkowie winni zatem zadanie rodzenia dzieci realizować w sposób naturalny. Nie powinni korzystać ze sposobów i metod, które są sprzeczne z naturą aktu małżeńskiego, samego małżeństwa lub jego celem. Nie powinni więc pozbawiać aktów małżeńskich ich naturalnej siły rozrodczej, choć mogą korzystać $\mathrm{z}$ naturalnej niepłodności, jeśli nie ingerują $\mathrm{w}$ naturalny przebieg aktu małżeńskiego. Zawsze jednak powinni zachować pozytywne nastawienie do przyjęcia potomstwa $^{35}$. Papież Paweł VI w encyklice Humanae vitae podkreślił, że chrześcijańscy małżonkowie powinni przekazywać życie w sposób odpowiedzialny, a więc mają stać się rodzicami odpowiedzialnymi. Odpowiedzialne rodzicielstwo jako zasada moralna oznacza obowiązek takiego postępowania małżonków w dziedzinie przekazywania życia, które jest zgodne z zamysłem Stwórcy i Zbawiciela, w odniesieniu do człowieka we wszystkich jego wymiarach. Prawdziwie odpowiedzialni rodzice są nastawieni pozytywnie na dar przekazywania życia, odrzucają więc negatywne i minimalistyczne nastawienie w podejmowaniu decyzji. Trzeba tutaj zaznaczyć, że postawa odpowiedzialności odniesiona do przekazywania życia wpisuje się w całościową koncepcję życia chrześcijańskiego w duchu wiary, nadziei i miłości. Dlatego też tylko ludzie z poczuciem odpowiedzialności za wypełnienie powołania chrześcijańskiego będą zdolni jako małżonkowie do odpowiedzialnego przekazywania życia w duchu nauki Kościoła, który kontynuuje misję zbawczą Jezusa Chrystusa ${ }^{36}$.

Z funkcją przekazywania życia jest integralnie złączona funkcja wychowawcza rodziny. Jan Paweł II nauczał, że rodzice nie tylko mają prawo do wychowywania swoich dzieci, lecz są do tego zobowiązani przez fakt rodzicielstwa: Zrodzenie co do ciała oznacza poczatek dalszego rodzenia, stopniowego $i$ wielostronnego rodzenia przez caty proces wychowania ${ }^{37}$. Z kolei innym razem stwierdził, że rodzić to znaczy zarazem wychowywać, a wychowywać znaczy

\footnotetext{
${ }^{34}$ Por. HV 14, 17. Por. także: EV 14, 63; DV IIA, 2 i 2B,4; M. M a c h i n e k: Życie $w$ dyspozycji człowieka. Wybrane problemy etyczne u poczatku ludzkiego życia. Olsztyn 2004 s. 118-139.

${ }^{35}$ Por. HV 14-17. Por. także: R. S z t y c h m i 1 e r : Obowiazek przekazywania życia $w$ rodzinie. „Chrześcijanin w Świecie”. R. 20: 1988 nr 12 s. 15.

${ }^{36}$ Por. J. N a g ó rn y: Istota odpowiedzialnego rodzicielstwa. W: Odpowiedzialni za życie $i$ miłość. Materiały z sesji naukowej zorganizowanej przez Duszpasterstwo Rodzin Diecezji BielskoŻywieckiej. Red. E. B u r z y k. Bielsko-Biała 1994 s. 45. Por także: T e n ż e: Teologiczne podstawy odpowiedzialnego rodzicielstwa. Na kanwie nauczania Jana Pawła II, W: Człowiek. Miłość. Rodzina..., dz. cyt., s. 223-246.

${ }^{37}$ LdR 16.
} 
rodzić. W człowieku, w którym to, co duchowe i co cielesne, wzajemnie się przenikaja, przenikaja sie też wzajemnie te dwie wielkie wymiary rodzicielstwa: rodzenie $i$ wychowanie $e^{38}$.

$\mathrm{Z}$ tego wynika, że ewangelizacja rodziny nie może być oderwana od wychowania. Wychowanie jest tą dziedziną, w której rola rodziny jest niezastąpiona. Rodzina poprzez wychowanie nie tylko wzrasta jako „Kościół domowy”, ale w obrębie Kościoła staje się podmiotem ewangelizacji i apostolstwa. Właściwe wychowanie powinno dotyczyć wszystkich dziedzin życia ludzkiego: biologicznej, emocjonalnej, psychicznej, społecznej, a zwłaszcza sfery religijnej i moralnej $^{39}$. Wydaje się jednak, że fundamentalne znaczenie $\mathrm{w}$ przeciwstawieniu się dzisiejszemu permisywizmowi moralnemu na płaszczyźnie wychowania ma właściwie ukształtowana sfera religijna i moralna ${ }^{40}$.

Papież Jan Paweł II podkreślał istotne znaczenie wychowania religijnego w rozwoju osobowym człowieka. Rodzice chrześcijańscy mają obowiązek zatroszczyć się, by pokazać dzieciom, do jakich głębin prowadzi wiara i miłość Jezusa Chrystusa ${ }^{41}$. Wiara przekazywana przez rodziców swoim dzieciom jest pierwszym sposobem spotkania się Boga z człowiekiem w rodzinie i przez rodzinę. Rodzice mają być więc przekazicielami Dobrej Nowiny wobec dzieci przez modlitwę, uczestnictwo w sakramentach świętych, lekturę Pisma Świętego, książek i czasopism religijnych i śpiew pieśni kościelnych. Szczególne miejsce zajmuje wspólna modlitwa oraz liturgia rodzinna związana z przeżywaniem w kręgu rodzinnym przyjęcia kolejnych sakramentów przez dzieci. To wszystko sprawia, że rodzice stają się dla swoich dzieci kapłanami ogniska domowego. W procesie wychowania religijnego duże znaczenie ma też wspólnotowe przeżywanie w rodzinie roku liturgicznego, jego okresów i świąt w duchu przepięknych tradycji przekazanych przez ojców. W ten sposób rodzina chrześcijańska staje się wspólnotą wierzącą i ewangelizującą, staje się znakiem Boga na ziemi ${ }^{42}$.

W dobie współczesnego kryzysu moralnego, wielorakich problemów i zagrożeń współczesnego świata niezwykle ważnym zadaniem jest wychowanie do

\footnotetext{
${ }^{38} \mathrm{~J}$ a n P a w e $\nmid$ I I: Przekażcie im to, co macie najlepszego. W: Dziecko w nauczaniu Jana Pawta II. Red. C. D r ą ż e k, J. K a w e c k i. Kraków 1985 s. 63.

${ }^{39}$ Por. Sobór Watykański II: Deklaracja o wychowaniu chrześcijańskim Gravissimum educationis. W: Sobór Watykański II. Konstytucje..., dz. cyt., nr 1. Podobnie stwierdza Kodeks Prawa Kanonicznego: Rodzice maja najcięższy obowiąek i najpierwsze prawo troszczenia się zgodnie, wedtug swoich możliwości, o wychowanie potomstwa zarówno fizyczne, społeczne i kulturalne, jak i moralne oraz religijne (kan.1136).

${ }^{40}$ Por. M. K 1 u z: Wychowanie chrześcijańskie $w$ rodzinie $w$ dobie permisywizmu moralnego. „Śląskie Studia Historyczno-Teologiczne”. R. 40: 2007 nr 2 s. 364-374.

${ }^{41}$ FC 39.

${ }^{42}$ Por. W. B o ł o z: Promocja osoby rodzinie. Warszawa 1998 s. 213-224.
} 
wartości moralnych ${ }^{43}$. To wychowanie młodego człowieka do wartości moralnych najpełniej realizuje się w rodzinie, gdyż to ona wywiera zasadniczy wpływ na życie człowieka. We współczesnej cywilizacji wychowanie do wartości moralnych $w$ rodzinie wymaga udzielania dzieciom podwójnego rodzaju pomocy wychowawczej. Należy, po pierwsze, demaskować błędne przekonania i postawy w odniesieniu do świata wartości, a po drugie, promować rzeczywiste, fundamentalne wartości moralne. Do najważniejszych wartości moralnych, należy zaliczyć: człowieczeństwo, sumienie, miłość, prawdę, wolność i odpowiedzialność oraz ludzką płciowość. Wychowanie, które nie wprowadzałoby młodego człowieka w świat tych fundamentalnych wartości, byłoby wychowaniem szkodliwym, zarówno dla człowieka jak i społeczności ${ }^{44}$.

W tej perspektywie jakże słuszne stają się słowa papieża Jana Pawła II: We wspótczesnym spoteczeństwie wychowanie do wartości jest bez watpienia najpowazniejszym wyzwaniem $^{45}$. W wychowaniu do wartości moralnych chodzi o to, by dzieci postępowały jak prawdziwi chrześcijanie, zdolni - przez wierność darowi wiary - do oświecenia i kształtowania społeczeństwa po chrześcijańsku. Trzeba więc dopomóc im w ocenie wartości moralnych wedle prawego sumienia i do przyjmowania owych wartości przez osobisty wybór, jak również w doskonalszym poznawaniu i miłowaniu Boga. To zadanie najlepiej może wypełnić zdrowa rodzina.

Trzeba jednak przyznać, że dzieło wychowania do wartości religijnomoralnych $\mathrm{w}$ rodzinie jest dzisiaj bardzo trudne, ze względu na obecne we współczesnym świecie - wspomniane już - zjawisko relatywizmu moralnego i wynikająca z niego postawa permisywizmu wychowawczego. Papież Benedykt XVI wzywa jednak do odważnego i zdecydowanego przeciwstawienia się naciskowi tej niszczącej ideologii. Do uczestników Kongresu Diecezji Rzymskiej w 2005 r. mówił otwarcie: Jest jasne, że musimy nie tylko przezwyciężać relatywizm $w$ naszej pracy formacyjnej z ludźmi, ale także przeciwstawiać się jego niszczycielskiej dominacji $w$ spoteczeństwie $i$ w kulturze. Dlatego bardzo ważna role odgrywa tutaj - obok stowa Kościoła - świadectwo i publiczne zaangażowanie chrześcijańskich rodzin, które przede wszystkim przypomina o nietykalności ludzkiego życia od poczęcia do naturalnego kresu, o wyjątkowej i niezastapionej roli rodziny opartej na matżeństwie oraz o potrzebie dziatań legislacyjnych $i$ administracyjnych wspierajacych rodzine $w$ jej misji wydawania na świat $i$ wy-

\footnotetext{
${ }^{43}$ Por. A. S a r m i e n to: Matżeństwo chrześcijańskie. Podręcznik teologii matżeństwa i rodziny. Kraków 2002 s. 408-413.

${ }^{44}$ Por. M. K $1 \mathrm{u}$ z: Wychowanie do fundamentalnych wartości moralnych $w$ rodzinie wyzwaniem cywilizacji. „Tarnowskie Studia Teologiczne”. R. 26: 2007 s. 113-129.

${ }^{45} \mathrm{~J}$ a n P a we 1 I I: Wychowanie cztowieka do wartości moralnych. „L'Osservatore Romano". Wydanie polskie. R. 15: 1994 nr 5 s. 17.
} 
chowywania potomstwa - misji o kluczowym znaczeniu dla naszej wspólnej przysztości ${ }^{46}$.

Posłannictwo ewangelizacyjne rodziny - obok tworzenia wspólnoty osób, służby życiu i dzieła wychowania - najpełniej wyraża jej uczestnictwo w życiu i misji Kościoła. Dla jego ukazania należy najpierw podkreślić szczególne więzi, jakie łączą Kościół z rodziną chrześcijańską: to nade wszystko Matka-Kościót rodzi, wychowuje, buduje rodzinę chrześcijańska, wypetniając wobec niej zbawcza misje otrzymana od Pana ${ }^{47}$. Ze swej strony rodzina chrześcijańska jest do tego stopnia wpisana w tajemnicę Kościoła, że staje się, na swój sposób, uczestnikiem zbawczego posłannictwa samego Kościoła. Wydaje się, że ową specyficzną więź istniejącą pomiędzy rodziną a Kościołem może oddać rozumienie rodziny jako „domowego Kościoła”. Mówiąc zaś o wzajemnym oddziaływaniu, można powiedzieć, że Kościół ewangelizuje i uświęca rodzinę, a rodzina nawzajem buduje i uświęca Kościół. Natomiast specyfiką misji rodziny jest jej charakter wspólnotowy, a więc wspólnie matżonkowie jako para, rodzice i dzieci jako rodzina winni przeżywać swoja stużbę dla Kościoła i dla świata ${ }^{48}$.

Rodzina chrześcijańska uczestniczy w misji ewangelizacyjnej poprzez odniesienie do potrójnej misji Chrystusa: prorockiej, kapłańskiej i królewskiej. Rodzina wypełnia swoje zadania prorockie przez przyjęcie i głoszenie Słowa Bożego. Staje się w ten sposób wspólnotą wierzącą i ewangelizującą, staje się znakiem Boga na ziemi.

Rodzina chrześcijańska jako wspólnota wierząca i ewangelizująca na mocy chrztu i bierzmowania pełni też funkcje kapłańskie. Rodzice wypełniają swoje zadania kapłańskie poprzez wspólnotowe uczestnictwo w sakramentach, zwłaszcza Eucharystii, składanie w niej duchowych ofiar, jak też przez inne akty kultu. Szczególne miejsce zajmuje tu wspólna modlitwa oraz liturgia rodzinna związana z przeżywaniem w kręgu rodzinnym przyjęcia kolejnych sakramentów przez dzieci. To wszystko sprawia, że rodzice stają się dla swoich dzieci kapłanami ogniska domowego ${ }^{49}$.

Rodzina chrześcijańska powinna być również gotowa do królewskiej służby człowiekowi. Powinna żyć szacunkiem dla drugiego człowieka i dostrzegać w nim godność dziecka Bożego. Nie może nigdy zasklepiać się w sobie, odizolo-

\footnotetext{
${ }^{46}$ B e n e d y k t X V I: Rodzina chrześcijańska wspólnota wychowania i wiary. Do uczestników Kongresu Diecezji Rzymskiej. „L'Osservatore Romano”. Wydanie polskie. R. 26: 2005 nr 9 s. 33.

${ }^{47} \mathrm{FC} 35$.

${ }^{48}$ Tamże, nr 49. Por. Cz. M u r a w s k i: Rodzina domowym Kościotem. W: Ewangelizacja wspólnoty matżeńskiej i rodzinnej. Red. E. S z c z o t o k, A. Li s k ow a c k a. Katowice $1993 \mathrm{~s}$. 92-101.

${ }^{49}$ Por. W. B o ł o z: Promocja osoby..., dz. cyt., s. 213-217.
} 
wywać się od otaczających ją ludzi, ale stanowić żywą wspólnotę miłości otwartą na innych ${ }^{50}$. Rodzina chrześcijańska jest też powołana do świętości. To wezwanie do świętości dotyczy wszystkich członków rodziny. Wszyscy w rodzinie mają więc obowiązek troszczyć się o wzajemne uświęcenie. Rodzina jest również wezwana do uświęcania wspólnoty kościelnej i całego świata. Jest to zadanie, które rodzina może i powinna spełniać w wewnętrznej komunii z całym Kościołem. W ten sposób staje się uczestnikiem zbawczego posłannictwa Kościo$\mathrm{la}^{51}$.

Rodzina, która cieszy się duchowym zdrowiem, znajduje się także w centrum uwagi Kościoła. Kościół ma świadomość ciążącej na nim odpowiedzialności za rodzinę i stara się jej przychodzić z pomocą. Kościół stale uświadamia rodzinie, czym jest i czym powinna być wedle zamysłu Boga. Umacnia i uświęca rodzinę przez sprawowanie sakramentów i przez głoszenie Słowa Bożego, zachęca ją do służby miłości ${ }^{52}$. Ale działanie Kościoła na rzecz rodziny nie ogranicza się tylko do głoszenia nauki. Kościół jest potrzebny rodzinie także w dziedzinie wychowania. Troska Kościoła o rodziny ujawnia się również w jego działalności duszpasterskiej ${ }^{53}$.

Należy jednak pamiętać, że rodzina jest nie tylko cząstką Kościoła. Jawi się ona także jako podstawowa komórka społeczeństwa, a to dlatego, że Stwórca wszechrzeczy ustanowit zwiąek matżeński początkiem i podstawa spoteczności ludzkiej ${ }^{54}$. Z tego wynika, że posłannictwo ewangelizacyjne rodziny wyraża się w jej współdziałaniu ze społeczeństwem. W rodzinie przecież rodzą się obywatele i w niej znajdują pierwszą szkołę cnót społecznych, które stanowią o życiu i rozwoju samego społeczeństwa. W rodzinie i dzięki niej człowiek rozwija swoją naturę społeczną, uczy się żyć z drugimi i dla drugich. Rodzina więc jest jedyną i niezastąpioną wartością dla społeczeństwa. Doświadczenie wspólnoty rodzinnej stanowi pierwszy i podstawowy wkład na rzecz społeczeństwa. Można powiedzieć, że rodzina warunkuje właściwy rozwój i trwanie społeczeństwa.

Ewangelizacyjne zadanie rodziny $\mathrm{w}$ życiu społecznym polega przede wszystkim na prokreacji i wychowaniu ${ }^{55}$. Rodzina jest najbardziej podstawową formą ludzkiego współżycia, odpowiadającą najważniejszym ludzkim potrzebom. Pozwala ona doświadczyć dziecku komunii i uczestnictwa, bezinteresownej akceptacji i poszanowania godności każdego człowieka. Rodzina stanowi pierw-

${ }^{50}$ Por. FC 17; LdR 6, 13.

${ }^{51}$ Por. W. B o ł o z: Promocja osoby..., dz. cyt., s. 223-224.

${ }^{52}$ Por. KDK 52.

${ }^{53}$ Por. FC 65-84.

${ }^{54}$ Sobór Watykański II: Dekret o apostolstwie świeckich Apostolicam actuositatem. W: Sobór Watykański II. Konstytucje..., dz. cyt., nr 11.

${ }^{55}$ Por. S. M o j e k: Powotanie do życia rodzinnego. W: Być chrześcijaninem dziś. Teologia dla szkót średnich. Red. M. R u s e c k i. Lublin 1992 s. 378. 
szą wspólnotę, do której człowiek przynależy. W niej spotyka ludzi różnych pokoleń, od których uczy się mądrości życiowej i podstawowych zachowań społecznych. Dlatego rodzina może i powinna przeciwdziałać depersonalizacji i innym wynaturzeniom społeczeństw. Ta zdolność rodziny do humanizowania życia społecznego nakłada na jej członków szczególną odpowiedzialność. Swoje wspólnototwórcze oddziaływanie rodzina powinna wypełniać w taki sposób, aby również osoby żyjące poza środowiskiem rodzinnym mogły doświadczyć wspólnotowej atmosfery ${ }^{56}$.

Każda rodzina powinna więc reagować i otwierać się na potrzeby społeczeństwa, a zwłaszcza innych rodzin. Niestety, ta otwartość rodziny na inne wspólnoty rodzinne, na społeczeństwa jest niekiedy zagrożona przez ograniczenie się tylko do własnych spraw. Rodzina została powołana do bytu przez Boga nie po to, aby się zamykała w sobie, lecz przeciwnie, by otwierała się na drugich, na inne rodziny. Tak więc solidarność i społeczność rodziny nie może ograniczać się tylko do członków własnej rodziny. Ta rodzina, która zamyka się tylko na własne sprawy staje się miejscem kultu egoizmu grupowego, a nie tym, czym powinna być: szkołą życia społecznego ${ }^{57}$.

Rodziny chrześcijańskie powinny chętnie podejmować różne dzieła służby społecznej, zwłaszcza na rzecz ubogich. Powinny otwierać się na ludzi samotnych, chorych, bezdomnych oraz przyczyniać się do umacniania sprawiedliwości, pojednania, braterstwa i pokoju między ludźmi. Rodzina bowiem jako „mały Kościół” jest powołana na podobieństwo „wielkiego Kościoła” do tego, aby być dla świata znakiem jedności ${ }^{58}$.

Oczywiście nie tylko rodzina pozostaje na służbie społeczeństwa, także społeczeństwo winno przyjść z pomocą rodzinie. To właśnie ono winno uznać, że rodzina jest społecznościa cieszaca się własnym pierwotnym prawem $^{59}$, zwłaszcza prawem do istnienia i rozwoju oraz pełnienia swoich zadań wewnętrznych i zewnętrznych. Społeczeństwo nie powinno pozbawiać rodziny takich zadań, które sama czy też we wspólnocie z innymi rodzinami może spełniać. W sumie społeczeństwo powinno w stosunku do rodziny przestrzegać zasady pomocniczości.

Społeczeństwo, a ściśle państwo, ma obowiązek czynić wszystko, co możliwe w celu zapewnienia wszelkiej pomocy, niezbędnej do normalnego funkcjonowania rodziny. Społeczność państwowa powinna stworzyć rodzinie warunki

\footnotetext{
${ }^{56}$ Por. W. B o ł o z: Promocja osoby..., dz. cyt., s. 186.

${ }^{57}$ Por. J. T ros ka: Moralność życia ptciowego, matżeńskiego i rodzinnego. Poznań 1994 s. 109.

${ }^{58}$ Por. FC 48.

${ }^{59}$ Sobór Watykański II: Deklaracja o wolności religijnej Dignitas humanae. W: Sobór Watykański II. Konstytucje..., dz. cyt., nr 5.
} 
odpowiedniej egzystencji, zabezpieczać jej wartości i dobra, pomagać realizować podstawowe cele, nie naruszając jednak jej autonomii. Państwo powinno zapewnić rodzinie prawo do rodzenia dzieci i do ich wychowania. Rodzice mają prawo decydować w sposób odpowiedzialny o wydaniu na świat dzieci. Instytucja rodziny powinna być przez społeczeństwo chroniona. Społeczność państwowa powinna popierać rodzinę również dlatego, że ma ona na celu, podobnie jak rodzina, ochronę i popieranie dobra osób w wymiarze indywidualnym i społecznym. Dwie instytucje, państwo i rodzina, są ze sobą związane organicznie i wzajemnie się w tych funkcjach uzupełniają. Chroniąc i popierając rodzinę, państwo przyczynia się do osiągania swoich własnych celów ${ }^{60}$.

W podsumowaniu trzeba powiedzieć, że nie od dziś wiadomo, iż poziom moralny społeczeństw zależy od poziomu życia poszczególnych małżeństw i rodzin. Można stwierdzić, że jaki jest poziom życia moralno-duchowego w rodzinach, takie też mamy społeczeństwo. Od losów rodziny zależą też losy świata. Przyszłość idzie więc przez rodzinę...

Nic więc dziwnego, że pod koniec Listu do Rodzin Jan Paweł II napisał: Poprzez rodzine tocza się dzieje człowieka, dzieje zbawienia ludzkości (...) rodzina znajduje się pośrodku tego wielkiego zmagania pomiędzy dobrem i ztem, między życiem a śmiercia, między miłościa a wszystkim, co jest jej przeciwieństwem. Rodzinom powierzone jest zadanie walki przede wszystkim o to, ażeby wyzwolić sity dobra, których źródto znajduje się w Chrystusie, Odkupicielu człowieka, aby te sity uczynić wtasnościa wszystkich rodzin, ażeby - jak to powiedziano $w$ polskim Milenium chrześcijaństwa - rodzina była »Bogiem silna ${ }^{61}$.

A zatem rozwiązywanie wszelkich konkretnych problemów moralnych musi łączyć się z odnalezieniem na nowo tego fundamentu małżeństwa i rodziny, którym jest Chrystus. Wcale to nie znaczy, że nie trzeba bardziej szczegółowo opisywać te współczesne problemy moralne małżeństwa i rodziny i jednocześnie ukazywać je jako swoiste zadania. Albowiem na problemy moralne trzeba zawsze patrzeć - od strony pozytywnej - jako zadania do zrealizowania, jako wyzwania, w których zawiera się także odwieczny plan Bożej miłości względem małżeństwa i rodziny. Kościół, który dostrzega wiele negatywnych znaków czasu w odniesieniu do życia małżeńskiego i rodzinnego płynącego z permisywnego myślenia, nie zatrzymuje się na ich opisie i na ich krytyce, ale odczytuje je jako konkretyzację tych zadań, które stawia przed rodziną Boże powołanie.

Oprócz więc jasnego przedstawiana chrześcijańskich zasad etycznych dotyczących małżeństwa i rodziny, Kościół powinien także jasno mówić, że to, co po

\footnotetext{
${ }^{60}$ Por. W. B o ł o z: Promocja osoby..., dz. cyt., s. 196.

${ }^{61}$ LdR 23.
} 
ludzku wydaje się niekiedy niemożliwe, jest możliwe u Boga, a więc możliwe jest do spełnienia dzięki Jego łasce, dzięki uczestnictwu już „tu i teraz” w Chrystusowym dziele zbawienia. I choć o nauce Kościoła - wtedy, gdy stawia on wymagania - mówi się niekiedy dzisiaj tak, jak mówiono o nauczaniu Chrystusa: Trudna jest ta mowa, któż jej może stuchać? (por. J 6,60), to jednak każdy kto czuje się powołany do życia z Chrystusem i obdarowany przybranym synostwem Bożym, powie za św. Piotrem: Panie, do kogóż pójdziemy? Ty masz słowa życia wiecznego $(\mathrm{J} 6,68)$. 